Вісник ЛНУ імені Тараса Шевченка № 5 (336), 2020

\title{
МЕНЕДЖМЕНТ ОСВІТИ
}

УДК 374-379(8)

DOI: $10.12958 / 2227-2844-2020-5(336)-176-183$

\section{Цибулько Людмила Григорівна,}

доктор педагогічних наук, професор кафедри педагогіки, доцент

ДВНЗ «Донбаський державний педагогічний університет»,

м. Слов'янськ, Україна.

luda.czibulko@gmail.com

https://orcid.org/0000-0003-1201-3215

Білецький Олексій Анатолійович, кандидат педагогічних наук, доцент кафедри педагогіки ДВНЗ «Донбаський державний педагогічний університет», м. Слов'янськ, Україна sovestalex@gmail.com https://orcid.org/0000-0002-8978-2218

Бондаренко Єлізавета Олегівна, магістрантка ДВНЗ «Донбаський державний педагогічний університет», м. Слов'янськ, Україна 2.ibonda18@gmail.com https://orcid.org/0000-0002-7796-4591

\section{ОРГАНІЗАЦІЯ І ЗМІСТ ГУРТКОВОЇ РОБОТИ}

У наш час позашкільна освіта, на відміну від загальноосвітніх установ, є одним з основних соціальних інститутів, що забезпечують виховний процес і розвиток індивідуальних здібностей дитини. 3 урахуванням віку й інтересів дітей, позашкільна освіта стає основою для виховання нового творчо мислячого покоління, професійної орієнтації, розвитку компетенцій, що вимагаються української спільнотою на сьогоденному рівні економічного і соціального розвитку держави.

Одним 3 найважливіших напрямів позашкільної освіти є гурткова робота. А робота дітей у гуртках може стати для них потужним стимулом у виборі майбутньої професії.

Проблемі організації гурткової роботи як у школах, так і у закладах позашкільної освіти приділялося багато уваги, як педагогами минулого століття (В. Сухомлинський, І. Підласий, С. Шацький, П. Блонський), так i сучасними науковцями. Серед сучасних праць вітчизняних педагогівнауковців виділяються грунтовні дослідження Н. Брижак, А. Воловик, В. Вербицького, О. Мелентьєва, О. Коберника у яких висвітлено основні питання теорії і методики позашкільної і гурткової роботи. 


\section{Вісник ЛНУ імені Тараса Шевченка № 5 (336), 2020}

Завдяки величезному широкому нагромадженню науковометодичного матеріалу, присвяченому позашкільній освіті, у статті буде проведена спроба виділення і систематизації деяких аспектів гурткової роботи.

Метою статті є вивчення механізмів організації і формування змісту гурткової роботи.

Новою «Стратегією розвитку позашкільної освіти» 2018 року фактично було затверджено позашкільну освіту, як пріоритетний напрям державної освітньої політики (Стратегія розвитку позашкільної освіти, 2018). Основою позашкільної освіти повинна стати гурткова робота. Отже, надалі ми будемо розглядати гурток, як основний вид діяльності в системі позашкільної освіти.

Гурток - це середовище спілкування й спільної діяльності, в якій можна перевірити себе, свої можливості, визначитися й адаптуватися в реаліях сфери, що зацікавила.

Гурток є найпоширенішою, традиційною формою добровільного об'єднання дітей.

Характерні ознаки гуртка:

1. Пріоритет предметно-практичних завдань.

2. Основний вид діяльності - навчання конкретному виду діяльності. Хоча це не означає відсутності виховних і розвиваючих завдань.

3. Навчання ведеться по одному предмету й одним педагогом.

Важливим елементом гуртка, його особливістю, $\epsilon$ i форма вираження підсумку, результату. Найчастіше він втілюється в конкретні й зовні ефектних показових виступах, концертах, фестивалях, диспутах, семінарах і тощо.

Гурткова робота в загальноосвітній школі й інших навчальних закладах, а також позашкільних установах проводиться 3 метою розширення загальних i поглиблення спеціальних знань учнів, задоволення їх індивідуальних інтересів і схильностей, розвитку творчих здібностей, а також з метою організації їх дозвілля.

Гурткова робота служить засобом професійної орієнтації учнів, у ній тісно переплітаються освітні й виховні завдання.

Гуртки організують у загальноосвітніх і професійних школах, вищих і середніх спеціальних навчальних закладах, у позашкільних установах, при клубах і бібліотеках на добровільних початках. Зазвичай у гуртку займаються 15-20 людей, при цьому кожний учень відвідує 1-2 гуртка, не більше.

У гуртках, особливо предметних, поєднуються учні одного віку, приблизно з однаковим рівнем підготовки. У деяких гуртках (xyдожніх, спортивних) об'єднання відбувається по інтересах, займаються учні різних класів (Т. Венгерак, 2010, с. 24).

Гурткова робота відрізняється від навчальної більшою різноманітністю форм і методів іiї організації. У початкових класах у 


\section{Вісник ЛНУ імені Тараса Шевченка № 5 (336), 2020}

гурткову роботу вносяться елементи гри й змагання. Вона проводиться в цікавих формах і не має яскраво вираженої спеціалізації. Тематика й зміст гурткових робіт звичайно відбивають новітні досягнення науки, техніки, мистецтва. Заняття в гуртках проводяться у формі бесід, рефератів, доповідей, екскурсії й походів, лабораторних і практичних робіт, виготовлення моделей i приладів, проведення дослідів i спостережень, змагань, участі в конкурсах і масових виступах.

Дуже важливо, щоб результати діяльності учнів у гуртках ставали надбанням усієї школи, або позакласного закладу освіти. Ця робота повинна мати суспільно-корисний характер, знаходити висвітлення в організації шкільних вечорів, конкурсів і олімпіад, диспутів, шкільних виставок, виставок дитячої творчості, шкільних музеїв. Вищою формою такої самоосвіти у колективі є різноманітні дитячі і юнацькі клуби.

Як зазначає Н. Брижак, «Позакласна робота в значній мірі бере свій початок на уроці і в цьому випадку $є$ логічним продовженням. Чим досконаліші методи викладання тим активні на уроці самі учні - їх думки, здібності, уявлення, тим реальніша потреба продовження пізнавальної діяльності в гуртках, клубах за інтересами, аматорських об'єднаннях, громадських організаціях, наукових товариствах» (Брижак Н.Ю, 2017, c.15).

Таким чином, основною виховною метою позаурочної i позашкільної діяльності $є$ соціально-корисна спрямування всіх видів діяльності, що охоплюються гуртковою роботою.

Всі справи, якими займаються діти під час навчання у гуртках, повинні бути пов'язаними з майбутньою суспільно-корисною діяльністю. Така діяльність починається з набуття корисних знань, умінь та навичок для себе і поступово повинна перерости у бажання працювати для близьких, для суспільства і держави.

Отже, гурткова робота є однією з важливих складових загального навчально-виховного процесу. Її цінність міститься у тому, що робота у гуртках є продовженням виховної роботи школи i формує у підростаючого покоління інтерес до історії народної творчості, до різних професій народного господарства.

Що стосується змісту гурткової роботи, необхідно зазначити, що різноманітні гуртки й клуби учнів створюються в загальноосвітніх школах, професійно-технічних училищах і інших навчальних закладах, у позашкільних установах, за місцем проживання.

За класифікацією Г. Терещука (Г. Терещук, Педагогіка і психологія, 1996) гуртки можна умовно розділити на такі групи:

- предметні (по навчальних предметах шкільної програми);

- суспільно-політичні (3 питань зовнішньої й внутрішньої політики, історії України, міжнародного дитячого, юнацького й молодіжного руху, з актуальних проблем сучасності тощо);

- технічні (науково-технічні, спортивно-технічні, виробничотехнічні, з окремих видів технічної творчості школярів); 


\section{Вісник ЛНУ імені Тараса Шевченка № 5 (336), 2020}

- натуралістичні (юних натуралістів, дослідників природи, за напрямками дослідницької роботи в школі);

- художньо-естетичні (образотворчої мистецтва, музичні, хорові, художньої самодіяльності);

- фізкультурно-спортивні (частіше називаються секціями; з усіх видів дитячого і юнацького спорту);

- туристсько-краєзнавчі (з краєзнавства, видів туризму, спорту, орієнтуванню).

Гуртками керують вчителі, працівники позашкільних установ, батьки, фахівці в різних галузях науки, техніки, мистецтва.

Незалежно від отриманої освіти у керівника гуртка, успіх гурткової роботи, зацікавленість у заняттях значною мірою залежать від його особистих якостей і професійної кваліфікації. Дітей в гуртки приваблює можливість виявити в роботі самостійність, ініціативу, одержати від старших товаришів слушну пораду.

Гурткова робота влаштовується і впроваджується на принципах добровільності й самоврядування. Сутність гурткової роботи полягає в тому, що певна теоретична або прикладна програма вивчається на основі самодіяльності колективу, на основі роботи школярів, організованих у гуртку.

Така колективна форма додаткової освіти має багато переваг перед індивідуальною, i iï значення в основному зводиться до наступних моментів.

а) Робота в гуртку має виховне значення. У співробітництві, при взаємній допомозі один одному, спільними зусиллями вирішуються якісь питання. 3 кожним новим заняттям навички цього співробітництва, взаємодопомоги, товариства, усе більше виробляються, і зміцнюються у гуртківців.

б) Робота в гуртку дає можливість більш глибоко й повно вивчати питання 3 технологій і краще засвоїти знання, а це дуже важливо. Окрім того, робота у гуртку заощаджує час, вона більш продуктивна, ніж індивідуальні заняття, коли дитина самотужки вимушена щось вивчати. Колективні (групові) заняття в гуртках дозволяють охопити великий обсяг навчального матеріалу, а також краще його засвоїти та одразу ж застосувати.

До переваг колективної форми самоосвіти перед одиночними заняттями також можна віднести привчання учасників до самодисципліни. Це відвідування гуртка в певні дні в означений час, дисципліна під час виконання завдань. Оскільки робота гуртка повинна відбуватися за строгим планом, робота кожного гуртківця також відбувається планомірно. Ніяких відкладань занять від дня на день, що легко трапляються без гурткових зобов'язань, не може бути.

Велику виховну роль у роботі гуртка відіграють наслідування й змагання. Слабка дитина, яка спостерігає успішну роботу інших, неминуче підтягується, прагне робити так само, наздогнати тих дітей, що 


\section{Вісник ЛНУ імені Тараса Шевченка № 5 (336), 2020}

встигають. Для гуртківців з більш-менш однаковими здатностями має значення й змагання. Один виступив, сформулював добре, іншої намагається зробити ще краще. Це змушує напруженіше працювати, уважніше проробляти матеріал до засідання кружка, 3'являється безпосередня зацікавленість у роботі (Позашкільна освіта в Україні: навч. посіб., 2006 р.). Беззаперечно, інтерес $є$ рушійною силою швидкого розвитку гуртківців, кращого засвоєння знань.

Однієї з головних завдань викладача $є$ пробудження інтересу до свого предмета, створення мотивації для його вивчення. Одним зі способів створення мотивації $є$ включення учнів у процес позакласної роботи. Заняття в гуртках $\epsilon$ добровільними, оцінок там нікому не ставлять. Займаючись у гуртку, учень керується тільки своїми інтересами. Він може вибрати інший, якщо $є$ така можливість. Заняття в гуртках надають дитині можливість максимально реалізувати свої таланти й можливості. Ї̈̈ пізнавальна активність розкривається у повній мірі, що можна використовувати й для засвоєння їм знань у суміжних або взаємозалежних галузях знань (Бондар, 2015, с. 254).

Вся система позакласної виховної (в тому числі і гурткової) роботи являє собою єдність цілей, принципів, змісту, форм і методів діяльності і включає безліч взаємопов'язаних елементів.

Метою такої системи є формування основ гармонічно розвинених особистостей, iї активної життєвої позиції, підготовка випускника школи до праці в розвиненому суспільстві.

Виховна система будується на основі певних принципів.

- Принцип наступності припускає створення й розвиток традицій, допомагає сформувати згуртований колектив, забезпечує стабільність і можливість удосконалювання різних видів діяльності, зв'язок поточної роботи з попередньої й наступної.

- Принцип масовості передбачає залучення всіх і кожної дитини в позаурочну виховну роботу.

- Принцип послідовності забезпечує єдину логіку в організації роботи, іiі плановість, виключає поява випадкових заходів, передбачає ускладнення змісту, форм і методів роботи з урахуванням вікових особливостей дітей.

- Принцип безперервності припускає правильне чергування напруг і спадів у роботі, рівномірність іiі в часі, іiі насиченість протягом не тільки навчального року, але й календарного року.

Висновок: Кожному вчителеві зараз відомо, що дає гурткова робота, і який величезний потенціал у ній закладений. Вона сприяє розвитку й підтримці інтересу учнів, підвищенню рівня їх практичних навичок, вихованню учнів, розширенню їх смаку, уяви, пам'яті й уваги, формуванню в них самостійності, організованості, точності й акуратності у виконанні доручених завдань і багато чого іншого.

Гурткова робота $є$ складовою частиною виховного й освітнього процесу. А необхідність зробити цей процес безперервним, обумовлює 
необхідність застосування позакласної роботи (у тому числі занять у гуртках). В. Сухомлинський про значення позакласної роботи писав: «Школа стає вогнищем духовного життя, якщо вчителі дають цікаві й по змісту, і за формою уроки... Але чудові блискучі уроки $\epsilon$ там, де $\epsilon$ ще щось чудове, крім уроків, де $\epsilon$ й застосовуються найрізноманітніші форми розвитку учнів поза уроками» (Сухомлинський, 1976).

Отже, гурткова робота має широкі можливості для залучення дітей до формування особистості, більше ніж звичайні шкільні заняття. Величезна розмаїть позаурочних виховних методик і прийомів дозволяє робити це всебічно.

\section{Список використаної літератури}

1. Брижак Н. Ю. Методика гурткової та клубної роботи в загальноосвітніх та позашкільних навчальних закладах: навчальний посібник. Київ: Логос, 2017. 126 с. 2. Венгерак Т. О. Система позакласної та виховної роботи. Світ виховання. 2010. № 1. С. 22-24. 3. Позашкільна освіта: теоретичні i практичні аспекти розвитку: монографія : у 3 кн. / [Л. М. Бондар та ін.; за заг. ред. Л. В. Тихенко]. 2-ге вид., випр. Суми: Університетська книга, 2015. Кн. 1. 2015. 270 с. 4. Позашкільна освіта в Україні: навч. посіб. / за ред. О. В. Биковської. Київ: ІВЦ АЛКОН, 2006. 224 с. 5. Терещук Г. В. Педагогічна діагностика ціннісних орієнтацій молоді в процесі іï соціального і професійного становлення. Педагогіка і психологія. 1996. №3. С. 119124. 6. Стратегія розвитку позашкільної освіти. Освіта. №35-36. 19-26 вересня 2018 року. Спецвипуск. 7. Сухомлинський В. О. Вибрані твори. В 5 томах. Т. 2. [Ред. колегія: Дзеверін О. Г. (голова), Черпінський М. В. та ін.]. К.: Радянська школа, 1976. 654 с.

\section{References}

1. Brizhak, N. Yu. (2017). Metodyka hurtkovoi ta klubnoi roboty v zahalnoosvitnikh ta pozashkilnykh navchalnykh zakladakh [Methods of Circle and club work in general education and extracurricular educational institution]. Kyiv: Logos [in Ukrainian]. 2. Venherak, T. O. (2010). Systema pozaklasnoi ta vykhovnoi roboty [The system of extracurricular and educational work]. Svit vykhovannia - The world of education, 1, 22-24 [in Ukrainian]. 3. Pozashkilna osvita: teoretychni i praktychni aspekty rozvytku: u $3 \mathrm{kn}$. [Extracurricular education: theoretical and practical aspects of development]. (2015). [L. M. Bondar ta in.; za zah. red. L. V. Tykhenko]. 2-he vyd., vypr. Kn. 1. Sumy: Universytetska knyha [in Ukrainian]. 4. Pozashkilna osvita V Ukraini [Extracurricular education in Ukraine]. (2006). Eds. O. V. Bykovskaya. K.: IVC Alcon [in Ukrainian]. 5. Tereshchuk H. V. (1996). Pedahohichna diahnostyka tsinnisnykh oriientatsii molodi $\mathrm{v}$ protsesi yii sotsialnoho i profesiinoho stanovlennia [Pedagogical diagnostics of value orientations of youth in the process of its social and professional formation]. Pedahohika $i$ psykholohiia - Pedagogy and psychology, 3, 119-124 [in 
Ukrainian]. 6. Stratehiia rozvytku pozashkilnoi osvity [Strategy for the development of extracurricular education]. (2018). Osvita - Education, 35-36, September 19-26. Special issue [in Ukrainian]. 7. Sukhomlinsky, V. A. (1976). Vybrani tvory [Selected Works]. In 5 volumes. Vol. 2. [Ed. board: O. G. Dzeverin, M. V. Cherpinsky et al.]. K.: Radianska shkola [in Ukrainian].

\section{Цибулько Л. Г., Білецький О. А., Бондаренко Є. О. Організація і зміст гурткової роботи}

У статті розглянуто основні моменти 3 організації i змісту позашкільної гурткової роботи, як однієї з найважливіших складових позашкільної освіти. Підкреслено необхідність подальшого розвитку гурткової роботи, як в межах загальноосвітньої школи (позаурочна робота), так і в рамках діяльності позашкільних закладів освіти. Було схарактеризовано основні ознаки, присутні будь-якому гурткові, підкреслено основні відмінності гурткових занять від шкільних уроків, у тому числі відмінності у формах методах викладання.

У статті також підкреслюється, що гурткова робота - це окрема форма навчання i виховання, яку доцільно називати колективною формою самоосвіти. На користь цього ствердження наводяться факти, що за формою навчання робота гуртка $\epsilon$ колективною, а за способом здобуття нових знань і формування умінь та навичок - індивідуальною. I має переваги як колективного навчання, так і індивідуального.

Ключові слова: гурткова робота, позашкільна освіта, гурток, пізнавальні можливості.

\section{Цыбулько Л. Г., Белецкий А. А., Бондаренко Е. А. Организация и содержание кружковой работы}

В статье рассмотрены основные моменты организации и содержания внешкольной кружковой работы, как одной из самых важных составляющих внешкольного образования. Подчеркнута необходимость дальнейшего развития кружковой работы, как в пределах общеобразовательной школы (внеурочная работа), так и в рамках деятельности внешкольных учебных заведений. Было охарактеризовано основные признаки, присущие любому кружку, подчеркнуты основные отличия кружковых занятий от школьных уроков, в том числе отличия в формах методах преподавания.

В статье также подчеркивается, что кружковая работа - это отдельная форма обучения и воспитание, которую целесообразно называть коллективной формой самообразования. В пользу этого утверждения приводятся факты, где по форме обучения робота кружка является коллективной, а за способом получения новых знаний и формирования умений и навыков - индивидуальной. Кружок несет в себе преимущества как коллективного обучения, так и индивидуального.

Ключевые слова: кружковая работа, внешкольное образование, кружок, познавательные возможности. 


\section{Tsibulko L., Biletsky O., Bondarenko E. Organization and Content of Group Work}

The article considers the main points of organization and content of club activity group work as one of the most important components of extracurricular education. The necessity of further development of circle work is emphasized, both within the General education school (club activity work) and within the framework of extracurricular educational institutions. It described the main features inherent in any circle, highlighted the main differences between circle classes and school lessons, including differences in the forms and methods of teaching.

Emphasis is placed on the mandatory publication of the results of the activities of the clubs members (holding exhibitions, fairs, reporting concerts and evenings) and its importance for the members of the club themselves. Based on the analysis of scientific literature, a classification of different types of circles is given, which is based on the main directions of socially useful activities of schoolchildren. It is proved that in order to achieve high results, group work should be based on the principles of voluntariness, humanism, democracy and self-government.

The article also emphasizes that group work is a separate form of education and upbringing, which should be called a collective form of self education. In favor of this statement, the facts are given, where the form of training of the club's activity is collective, and the method of obtaining new knowledge and forming skills is individual. And it has the advantages of both collective and individual training.

Key words: group work, extracurricular education, club, club activity.

Стаття надійшла до редакції 13.10.2020 р.

Прийнято до друку 27.11.2020 p.

Рецензент - д. п. н., проф. Савченко С. В. 